\title{
Denialism in an Age of Human Rights Hegemony
}

Denialism can be effective, especially when powerful and influential actors repress dark chapters of history that the populace already seeks to avoid. Yet denial of mass atrocity and genocide in the context of human rights hegemony is likely to fail. In fact, denialists have to expect counterproductive consequences. Their "successes" turn out to be Pyrrhic victories.

To argue this point, I briefly return to central insights from the two preceding chapters. There I examined epistemic conflicts in the context of legal and political decision-making processes. Both chapters taught us important lessons about the social forces at work, the entrepreneurs of knowledge and carrier groups, the effect that rules of the game have on fights carried out in specific social fields, the limits of those rules when players improvise, and the weight of national contexts in which fields are nested.

Yet focusing on concrete processes of decision making alone leaves out something important. It does not speak to situations in which problems never become issues in the first place, in which they do not enter public consciousness and are absent from the realm of deliberation and decision making. Scholarly debates of the 1960 s and 1970 about community power structures can teach us important lessons about such blank spots. These debates initially involved two camps. One camp used a conflict theoretical model inspired by C. Wright Mills and took a reputational approach to measuring power, asking experts or members of local elites about the amount of power held by different actors in the community. The resulting image was that of a steep hierarchy, resembling a pyramid. The other camp used a pluralist model, following political scientist Robert Dahl. Its proponents inquired about specific decision-making issues that came before city councils. They identified involvement of diverse groups and shifting coalitions with variable outcomes, depending on the issues at stake. Findings of this school were in line with a schoolbook model of American democracy and a pluralist notion of American politics. 
Both schools, however, overlooked that some problems, often the most fundamental ones, were never articulated. Peter Bachrach and Morton Baratz (1970), in a groundbreaking study of the city of Baltimore, found that no city leader and no constituent group articulated the issue of poverty, an overwhelming condition for many of its (minority) residents. Nor did any leader or interest group have to intervene to keep the problem of poverty out of public view. Similarly, air pollution never became an issue in some municipalities (but it did in others), and patterns of issue making were independent of the actual concentration of pollutants in the respective cities (Crenson 1972). In other words, hegemonic thought can keep a problem off the radar of public engagement and policy making.

Just as hegemony can keep a problem away from the realm of concrete decision making, it may frustrate efforts of those who seek to hide an issue that hegemonic thought embraces. When actors attempt to initiate and color the outcome of concrete decision-making processes with the intent to deny grave violations of human rights, then they are likely-in the current era of a human rights hegemony-to encounter counterproductive consequences. Both the Griswold v. Driscoll court case in Massachusetts and the memory legislation in France serve as examples.

In this concluding chapter, I explore such counterproductive consequences of denialist actions in the context of a human rights hegemony. I do so both for cases analyzed in the preceding chapters and for denialism of the Armenian genocide more broadly, using media reporting and documentary films for data. A brief terminological clarification of human rights hegemony, however, is warranted at the outset.

\section{HUMAN RIGHTS HEGEMONY}

By human rights hegemony, I mean the domination of a mode of thought that submits events and phenomena to a specific interpretation, as consistent with, or in violation of, human rights. The term hegemony derives from the work of Italian neo-Marxist thinker Antonio Gramsci. While I borrow the term from Gramsci, I do not limit hegemony to class-based hegemony. Instead, I see additional forces at work, invoking their power, including "soft power." I do, however, follow Gramsci's focus on universal acceptance, taken-for-grantedness, and the special attention he pays to the potential role of the state and its ability to "regulate beliefs within civil society" (Smith and Riley 2009:36). In addition to the state as a contributor to hegemony, Gramsci alerts us to "organic intellectuals," including journalists and priests who translate complex themes into everyday language to instill them in the minds of readers and believers. Today, journalism is still a powerful force, but other interpreters-such as filmmakers, social movement actors, and nongovernmental organizations (NGOs) - often take on the role previously fulfilled by clerics (Levy and Sznaider 2010; Keck and Sikkink 1998). 
Structural and cultural changes, reinforced by historical contingencies, advanced the notion of human rights. Transformations such as global interdependencies and the advancement of human rights NGOs were undergirded by contingencies such as the catastrophes of World War II and the Holocaust to promote a new focus on the dignity of individuals. Human rights hegemony now accepts the rights granted each human being, even if these rights are often underenforced. It is expressed in the Universal Declaration of Human Rights and in the protections promised to members of social categories such as ethnic, racial, religious, and national groups by the Convention on the Prevention and Punishment of the Crime of Genocide and by the Rome Statute of the International Criminal Court. Human rights hegemony challenges actors who seek to deny the recognition of victims of grave violations against human rights norms. Those who bear responsibility for massive human suffering may have been seen as heroes for much of human history, but contemporary institutions increasingly classify them as criminal perpetrators.

Human rights hegemony experiences blowback in times of right-wing populist movements and authoritarian leaders, even in Western democracies such as the United States. Its principles certainly clash with concentration camps, euphemized as reeducation facilities in China; mass killings of "infidels" by militant "Islamists"; murderous campaigns in the name of drug control in the Philippines; arbitrary imprisonment of scholars, journalists, and others in Turkey; and large refugee populations worldwide. Yet none of the above go unnoticed, and perpetrators see reason to hide their deeds or to use coded language. For example, they call torture "enhanced interrogation" and use new torture methods that do not leave traces on the body (Senate Select Committee on Intelligence 2014). They know that their deeds evoke outrage if they reach the eyes of a world public. Their attempts at cover-up only show that today we live with a taken-for-granted notion that humans are carriers of certain unalienable rights. We live in an era of-at least partial-human rights hegemony.

\section{COUNTERPRODUCTIVE CONSEQUENCES \\ OF DENIALISM IN A TIME OF HUMAN \\ RIGHTS HEGEMONY}

In a time of human rights hegemony, state actors are tempted more than ever to deny or to neutralize grave violations of human rights. Yet they face challengers, and their denialism generates counterproductive consequences. Both the Massachusetts case and the French legislative story support this thesis.

\section{The Griswold v. Driscoll Court Case}

The legal conflict over teaching guidelines pertaining to the Armenian genocide in the state of Massachusetts showed that formal legal processes, constrained by 


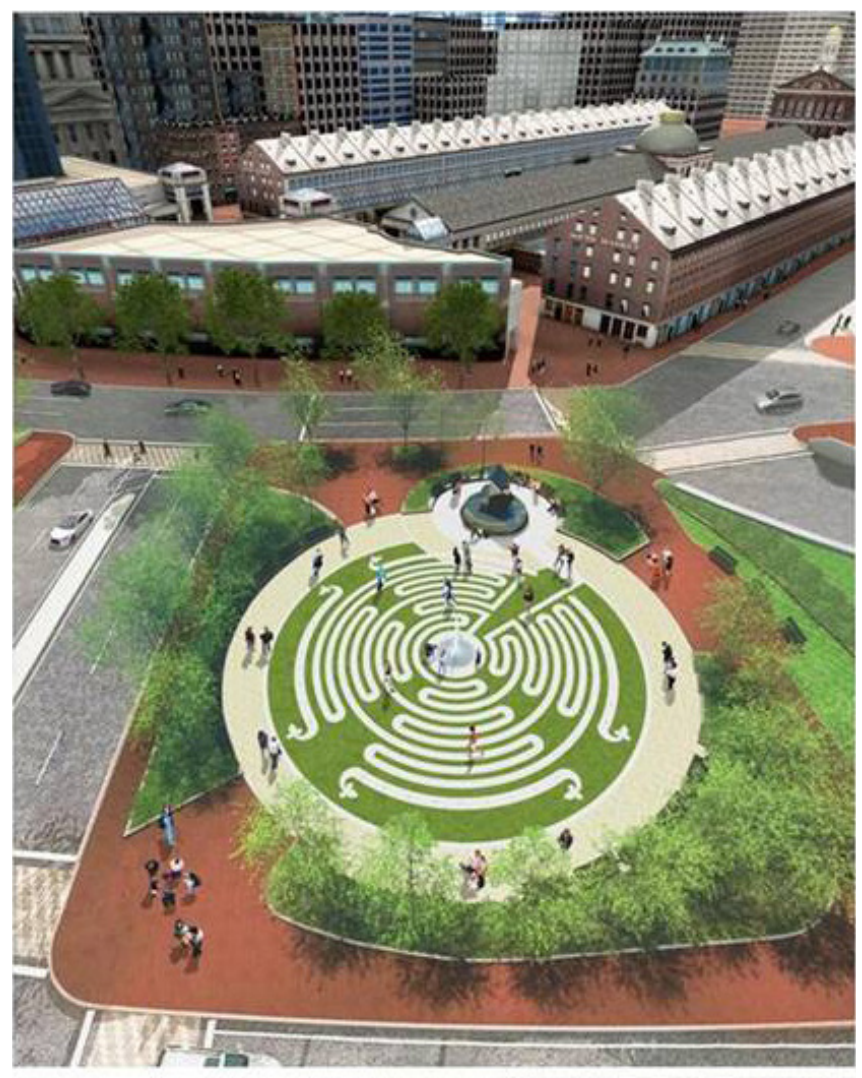

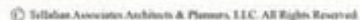

FIgURE 13. Armenian Heritage Park in Boston. Photo courtesy of the Armenian National Institute.

the logic of law, nevertheless have substantive consequences. ${ }^{1}$ While Griswold v. Driscoll shaped the law by clarifying the extent of government speech protections in the realm of public education, ${ }^{2}$ the court proceedings also provided a stage for the presentation of claims about the Armenian genocide, most noteworthy in various amicus briefs.

Most importantly, the case mobilized Boston's Armenian American community and supporting groups, with detrimental consequences for those who initiated the court case with denialist intent. A lawyer and high-ranking official with the Armenian Association of America reports how, in the midst of Griswold v. Driscoll, an Armenian Heritage Foundation was formed with the goal of building a memorial space on the Boston Greenway. Ground was broken a year after the court case concluded (Armenian Weekly 2012). Called the Armenian Heritage Park, the area features green space, a fountain, and seating (see figure 13). It provides 
information about the Armenian genocide, as well as personalized panels that individuals dedicated to prominent Armenian Americans and Armenians, including those killed in the genocide. The outcome is all the more remarkable in that the Boston Greenway, a mile-long park near the Boston Harbor, was originally mandated to not include culturally specific memorial spaces. ${ }^{3}$ Numerous respondents to our study commented on the link between the Griswold v. Driscoll case and the creation of the memorial. They tell how efforts toward realization of this project had been stagnant until the case provoked support by local Armenian Americans and the public. They believe that the eventual construction of the Armenian Heritage Park succeeded, at least in part, because of successful fundraising mobilized by the court case.

The court case also mobilized other local groups that live with the cultural trauma of past mass violence. The local branch of the Anti-Defamation League (ADL), a Jewish international NGO, for example, originally took no stance on Griswold v. Driscoll. Yet, after neighboring communities threatened to draw out of their Holocaust remembrance campaigns and after pushback from national headquarters, the local ADL began to support Armenian American groups in their legal mission.

Finally, the Armenian success advanced the struggle for recognition of the plight of other groups, for example in 2018, when the Massachusetts Board of Education released a new history and social studies framework. The development of this guide again provided an avenue for public feedback. This time, a group of Ukrainian Americans contacted the Department of Education, requesting that the Holodomor, the Stalinist-induced mass famine in Ukraine, be included in the new document. The updated curriculum guide now lists this famine, depicting it as a Ukrainian genocide. An interviewee from the Board of Education explained the emotionality of this inclusion for her contacts within the Ukrainian American community. Their letters and statements had contributed to the curricular innovation, and the addition "elated" them.

In short, attempts to prevent the inclusion of the Armenian genocide in the Massachusetts curriculum guidelines, or to neutralize them through the inclusion of denialist materials, were defeated in court. Importantly, in the context of human rights hegemony, these attempts contributed to community mobilization that eventually resulted in the strengthening of public acknowledgment of the Armenian genocide and of other occurrences of mass violence. Denialist efforts, in this cultural context, yielded counterproductive consequences for those who engaged in them.

\section{The French Legislative Case}

In France, too, despite the Constitutional Council overruling the 2012 criminalization of denial of the Armenian genocide, the consequences of the struggle substantially supported the acknowledgment agenda. Here, too, the legislative 


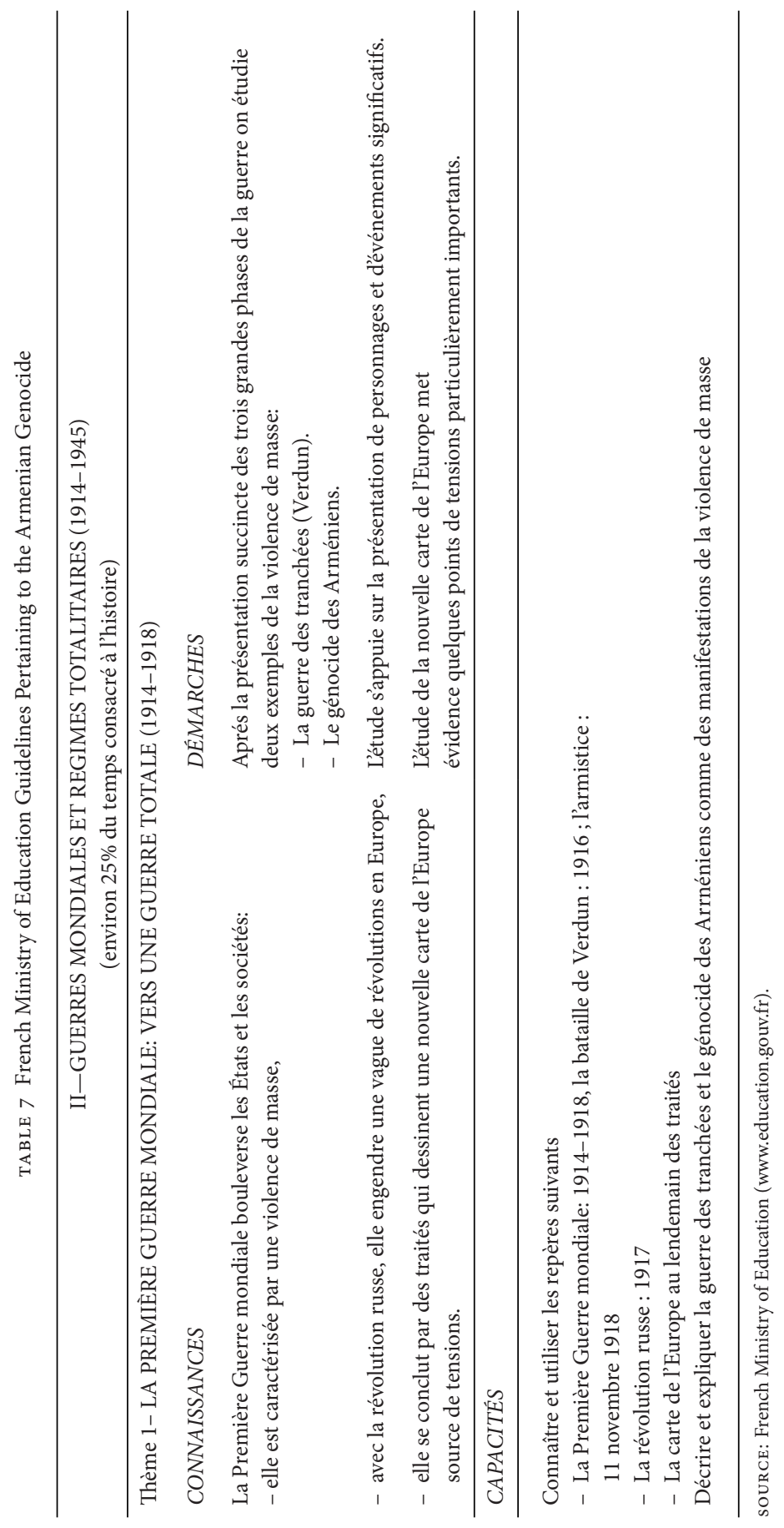


process - and upset over massive interventions by the Turkish state beginning in the late 1990s-had mobilized ethnic Armenians and their supporters. After the CC struck down the law, mobilization intensified and induced other means to meet substantive demands for recognition.

Already in 2008, the French government had decided that the Armenian genocide should be included in history curricula (see table 7). Guidelines promulgated by the French Ministry of National Education, Higher Education and Research specify subjects to be covered in the French equivalent of ninth grade: "II. WORLD WARS AND TOTALITARIAN REGIMES (1914-1945) (about 25\% of time dedicated to history). Theme 1 'THE FIRST WORLD WAR: TOWARD TOTAL WAR (1914-1918). KNOWLEDGE. The First World War shook states and societies: It is characterized by mass violence. ... PROCEDURE: After the succinct presentation of the three phases of the war, two examples of mass violence are to be studied: trench warfare (Verdun) and the genocide against the Armenians. . . . To describe and to explain the trench warfare and the genocide against the Armenians as manifestations of the mass violence" (Bulletin officiel spécial nº 6 du 28 août 2008, p. 41; translation and emphasis by author) ${ }^{4}$

Further specifications followed the defeat of the 2012 law aimed at the criminalization of genocide denial. These culminated in the April 2015 promulgation of a teaching aid by the Ministry of National Education. Authored by historian Vincent Duclert, the teaching aid is entitled Le Genocide des Arméniens Ottomans: Mise au point scientifique et pédagogique pour les enseignements (The genocide against the Ottoman Armenians: scientific and pedagogical focus for instruction). The ministry's introduction states: “The transmission of such knowledge is central to the mission of schools because the Armenian genocide figured prominently in historical programs, especially in mandatory schooling, but also because the necessity to know and the study of a world confronted by such trauma are part of the ambitions of moral and civic education. ... We also requested that Vincent Duclert, Inspector General of National Education, simultaneously historian and scholar of the Armenian Genocide, propose resources on this subject. He proposes here an easily accessible synthesis that summarizes that history and addresses the challenges of its transmission" (Duclert 2015, translated).

This excerpt states that the highest national authority in the realm of education asked an actor at the intersection of scholarship and political administration to summarize, and provide resources that communicate to teachers, knowledge about the Armenian genocide and sources for instructional purposes. The guidelines' central tenets confirm Armenian knowledge. A brief chapter on the genocide, as the first event of this kind in contemporary history (modified in the text by a recognition of the German genocide in today's Namibia), is followed by a central chapter entitled "1915-1923. The Destruction of the Armenians of the Ottoman 
Empire." A history of oppression preceding World War I follows, informing readers about the Armenians as an ancient, faithful, and vulnerable population in the Ottoman Empire. It addresses the "genocidal" massacres under Sultan Abdülhamid II in the years 1894-96; the Young Turk revolution with its hopes for democratization, defeated by nationalist radicalization; total war and the release of exterminationist forces; phases of the genocide; and weak punitive responses in the aftermath of World War I. A final chapter addresses the state of historical research under the title "Scientific progress and struggle against denialism." A brief paragraph shows that the basic contours of knowledge communicated here are in line with sedimented knowledge within Armenian communities and with dominant scholarship, and are detrimentally opposed to Turkish knowledge: "At the heart of the First World War, between 1915 and 1917, the Ottoman Armenians, who formed the most important among the non-Muslim communities of the Empire, endured a programmed destruction, efficiently and effectively executed. Sixty percent of the population, some 1.3 million men, women and children disappeared, were massacred through numerous techniques with a cruelty that surpasses the limits of comprehension and marks a fall into the darkness of inhumanity" (Duclert 2015:4, translated).

Other initiatives in the realm of higher and public education, some stateinitiated, others originating in civil society, parallel these educational efforts. The year 2013, for example, witnessed the foundation of a Conseil scientifique international pour l'étude du génocide des Arméniens (an international scientific council for the study of the Armenian genocide), which organized a major international colloquium on the subject in the Grand Amphitéatre of the Sorbonne University. Furthermore, in 2015, the centennial year of the Armenian genocide, two prominent exhibits on the genocide took place in Paris, one in the Hôtel de Ville (city hall), the other at the Mémorial de la Shoah, the official French Holocaust memorial (see chapter 4). Numerous magazines chose to display the event on their cover pages, prominently visible on kiosks throughout Paris.

A few years later, in February 2019, President Emmanuel Macron lived up to a promise he had made during his election campaign. He issued a decree declaring April 24, the day on which Armenians remember the genocide, an official national memorial day of the French Republic (see box 1). President Macron explained his decision in these words: "France is above all a country, which knows how to look history in the face ... among the first to denounce the murderous manhunt of the Armenian people in the Ottoman Empire ... , which-already in 1915-called the genocide for what it was: a crime against humanity, against civilization. Which, in 2001, after a long struggle, recognized it by law, and which - as I promised to do-will make April 24 in the coming weeks a national day of commemoration of the Armenian Genocide" (in Le Monde, February 2019, translated). 
BOX 1. Decree by President Emmanuel Macron Declaring April 24 an Official French Memorial Day. Source: Legifrance (www.legifrance.gouv.fr).

\section{Décret $n^{\circ} 2019-291$ du 10 avril 2019 \\ relatif à la commémoration annuelle du génocide arménien de 1915}

\section{NOR : PRMX1820266D}

Le Président de la République,

Sur le rapport du Premier ministre,

Vu l'article 37 de la Constitution ;

Vu la loi n²001-70 du 29 janvier 2001 relative à la reconnaissance du génocide arménien de 1915, Décrète :

Art. $\mathbf{1}^{\mathrm{er}}$. - La date de la commémoration annuelle du génocide arménien de 1915 est fixée au 24 avril.

Art. 2. - Chaque année, à cette date, une cérémonie est organisée à Paris.

Une cérémonie analogue peut être organisée dans chaque département à l'initiative du préfet.

Art. 3. - Le Premier ministre est chargé de l'exécution du présent décret, qui sera publié au Journal official de

la République française.

Fait le 10 avril 2019.

Par le Président de la République :

Le Premier ministre,

EDOUARD PHILIPPE

Observations at the first official commemoration show how a presidential decision translates into practice. On April 24, 2019, a large crowd gathered at the Armenian genocide memorial of Paris, the Komitas statue. This statue is a sixmeter-high representation of Father Komitas, a priest and scholar of Armenian music, a survivor of the genocide, and a refugee to France. It stands prominently at the entrance to Yerevan Park (Jardin d'Erevan), at the northern end of the Pont des Invalides and close to the Grand Palais. It serves as a commemorative monument to the Armenian victims of the genocide and to those Armenians who fought and lost their lives in French military service and in the Résistance against Nazi German occupation. The City Council of Paris voted for its establishment on January 29,2001 , the day on which the legislature passed the recognition law, and the inauguration followed in 2003.

On the memorial day of 2019 , close to the statue and with its back to the river Seine, stood a temporary stage with the inscription "Commemoration Nationale du Génocide Arménien." Around the stage, a first security perimeter was reserved for dignitaries, ministers, prefects, mayors, legislators, ambassadors, and leaders of the Armenian community. An outer perimeter began to fill with a mostly French Armenian crowd at 5 p.m. Bags and purses were checked at the entry points. By 6 p.m. an estimated two thousand people had gathered, and the official ceremony began half an hour later. Many in the crowd held up posters with the words "Génocide Arménien. 24 Avril. Journée Nationale de Commémoration. 1915-2019. Mémoire et Justice." Others waved French or Armenian flags. The symbolic display, and the ritual itself, demonstrated unity between the Armenian and 


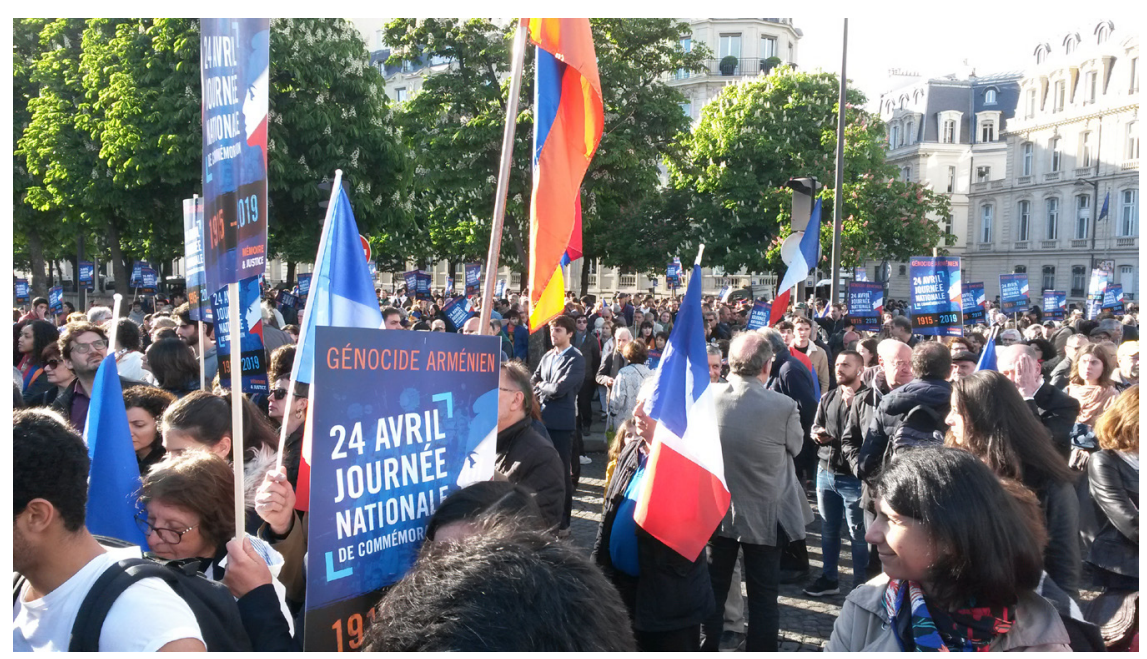

FIGURE 14. A crowd gathered in Paris for the first national day of commemoration of the Armenian genocide, April 24, 2019. Photo by the author.

French nations and their joint memory of the genocide against the Armenians of the Ottoman Empire (see figure 14).

The ceremony included the playing of the Armenian and French national anthems, the laying of wreaths at the memorial, and four speeches. Mourad Franck Papazian and Ara Toranian, copresidents of the Coordination Council of Armenian Organizations of France, delivered the first speeches. ${ }^{5}$ The event culminated in speeches by Anne Hidalgo, mayor of Paris, and Édouard Philippe, prime minister of France.

All speeches specified the close alliance between Armenians and the French nation. They referred to Armenian immigrants who became heroes in the fight of the Résistance against Nazi Germany's occupation, famous among them Missak Manouchian, and to those who became national treasures in the world of arts such as chansonnier Charles Aznavour. Importantly, all speakers confirmed the Armenian repertoire of knowledge concerning the mass violence against the Armenians in 1915 and subsequent years, as illustrated by a quotation from Prime Minister Philippe:

Between April 1915 and July 1916, one million Armenians disappeared, their blood shed, burned alive. The massive deportations transformed the Anatolian highways into routes of death. Women and children of all ages were martyred. An industrious people with a millennial history that had contributed much to the prosperity of the Ottoman Empire experienced a methodical and organized attempt at annihilation.

The Armenians were put to death, as a people, because they were "guilty of being children of Armenia." Because they embodied an ethnic and Christian minority, thus a difference. The specificity of genocide is that one is guilty of being oneself. ${ }^{6}$ (translated) 
Conceding that the 2001 recognition law alone does not do sufficient justice to history, the prime minister stressed the need for this day of commemoration to secure the memory of the Armenian genocide. He challenged denialism, but-different from the two copresidents-he did not explicitly refer to Turkey and its current government as denialists and aggressors. Instead, he offered an olive branch and encouraged cooperation, stating, "For a long time already, ladies and gentlemen, courageous voices engage in the labor of memory and dialogue between Turks and Armenians. This day of commemoration of the Armenian genocide, of that we are convinced, is a day of peace. This day is not being celebrated to the detriment of any people" (translated).

In short, like the Massachusetts court case, the French story shows that massive opposition to genocide recognition, in an age of human rights hegemony, backfires. Acknowledgment of the genocide intensifies and is diffused. The knowledge repertoire of the victimized group enters into the edifice of hegemonic thought. ${ }^{7}$ It solidifies and becomes further sedimented. In line with Gramsci's arguments, the state and "organic intellectuals" play key roles in this process. Gramsci's identification of media as another transmitter of hegemonic thought suggested an examination of media reports and documentary films.

\section{Effects of Denialism: Contention in Western Media Reporting}

Media reflect and transmit articulations by knowledge entrepreneurs-and the public events they initiate, including rituals and legislative and judicial proceedingsthereby enhancing hegemonic thought and communicating it far into civil society. Simultaneously, media filter articulations and events through their own institutional logic. Pierre Bourdieu characterized journalism as "a microcosm with its own laws, defined both by its position in the world at large and by the attractions and repulsions to which it is subject from other such microcosms" (1998:39). He appropriately depicted these microcosms as relatively independent or autonomous fields, following their own "rules of the game." Journalistic depictions of the world thus cannot be read, for example, as simple reflections of economic interests-even if pursuit of such interests is vital to the operation and survival of a newspaper or TV station.

While highlighting internal rules of the game, Bourdieu's argument is not necessarily contradictory to Gramsci's point about journalism's role in hegemonic thought. The field's rules, after all, are informed by its "position in the world at large" and by "attractions and repulsions from other fields." Bourdieu thus refines Gramsci's argument: news media's rules of the game are themselves affected by the environment in which they operate. Media are only relatively autonomous. While they must bolster legitimacy by projecting a sense of procedural fairness, they also depend on markets, thereby securing survival (and profits), and on sources of information.

All of this matters here because media pay attention to the judicial, legislative, and ritual events surrounding struggles over Armenian genocide recognition and denial. Even a simple count of all reports on Armenian issues in U.S. newspapers of record (New York Times, Washington Post, Wall Street Journal) and in renowned 


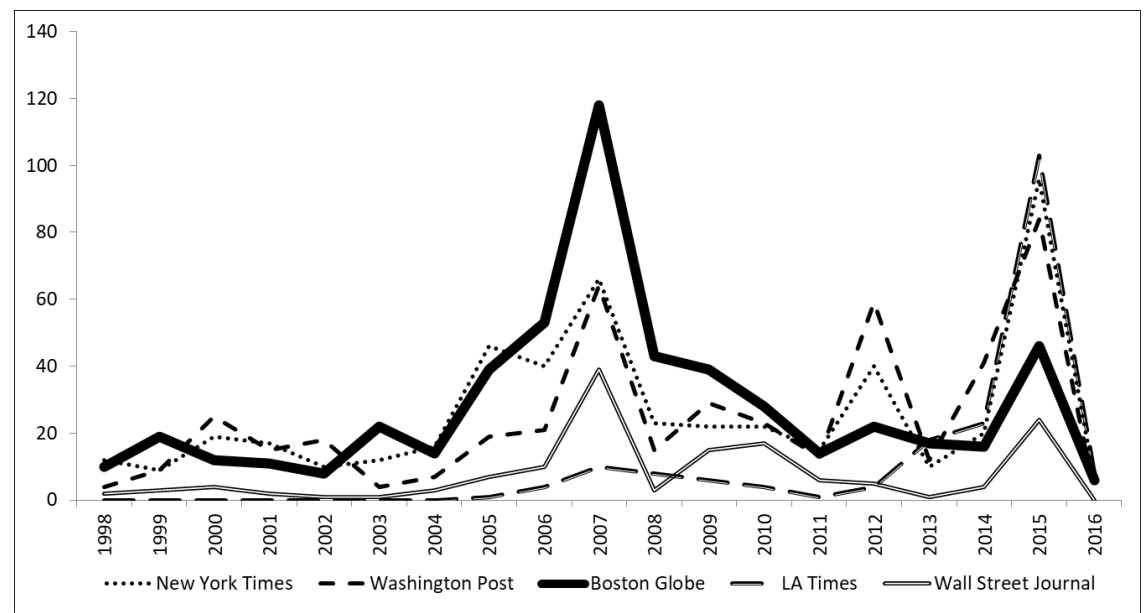

FIGURE 15. Frequency of reporting on Armenian affairs in selected U.S. newspapers.

papers from those regions that are home to the majority of diaspora Armenians (Los Angeles Times, Boston Globe) reveals remarkable patterns.

Figure 15 displays, by years, peaks and valleys in the frequency of reporting on Armenian issues. Three peaks stand out: 2007 and surrounding years, 2012 (albeit less pronounced), and 2015. Each peak speaks to an event analyzed in the preceding chapters. The years around 2007 witnessed the unfolding of Griswold v. Driscoll. Since that case was about Massachusetts teaching guidelines, it is not surprising that this peak of reporting is especially high for the Boston Globe. In 2012, the year of the second peak, the French legislature passed the law criminalizing denial of the Armenian genocide, and France's Constitutional Council overruled that legislative decision. This peak shows that important political events pertaining to the memory of the Armenian genocide register in U.S. reporting, even when they unfold abroad. Finally, 2015 is the centennial of the Armenian genocide, an event commemorated by Armenian communities and their supporters in Armenia and in the diaspora (see chapter 6). Media reported these rituals widely and thereby transformed public events into cultural events, multiplying their effects on collective perceptions (Dayan and Katz 1992).

What, then, do journalists write when they address the Armenian genocide and struggles over its recognition? An analysis of a random sample of 301 articles from English-language newspapers in various countries around the globe and of 265 French media reports provides answers. For the latter, we selected articles published in Le Monde, the leading center-left daily newspaper, and in Le Figaro, the most prominent center-right paper of record in France. The period included in the analysis is from 1998, just preceding the French legislation recognizing the Armenian genocide, to the beginning of 2016, the year after the centennial commemoration. 


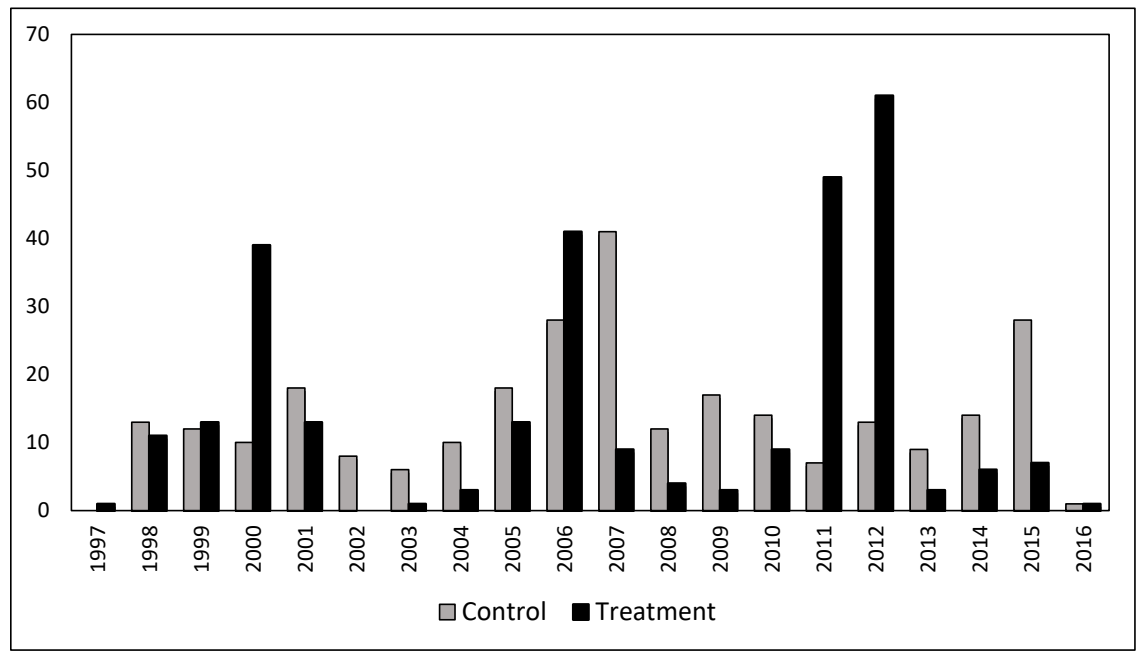

FIGURE 16. Frequency of reports in news media sample, by treatment vs. control group, over time.

Out of the articles we selected, seventy-four English-language pieces and 179 French articles addressed the French legislative process. Twenty-nine articles in English (and no French articles) engaged with the Griswold v. Driscoll court case. Given my interest in effects of legislative and legal struggles on knowledge, I refer to these as treatment cases. I refer to other articles that speak directly to the Armenian genocide as control cases.

Figure 16 shows that the distribution of this sample of articles over time is quite similar to that for the population of articles in U.S. newspapers shown above, confirming that the events we are interested in resonate transnationally. In addition, debates over the 2001 French recognition law are reflected in the sample, adding an additional peak in reporting. Figure 16 also shows a noteworthy specification: peaks surrounding major legislative decisions are due to articles that focus on debates over recognition as opposed to articles about the genocide per se. The peak of the 2015 centennial instead results primarily from reporting on the genocide itself. Figure 16 further indicates that political struggles $(2000,2011-12)$ are less likely than a court case (2006-7) to evoke reports about the genocide as such. At the expense of reporting history of the genocide itself, politics keeps journalistic attention focused on controversies carried out by highly visible political actors, compared to judicial proceedings or memorial events. The following, then, is a significant takeaway from this analysis: Commemorative events, and even court trials, are more likely than political struggles over recognition to direct public attention toward the events of the genocide per se.

Content analysis of the sample of 566 articles reveals the structure of representations of the genocide and of disputes over its recognition, the time and place of publication, and voices cited. ${ }^{8}$ 


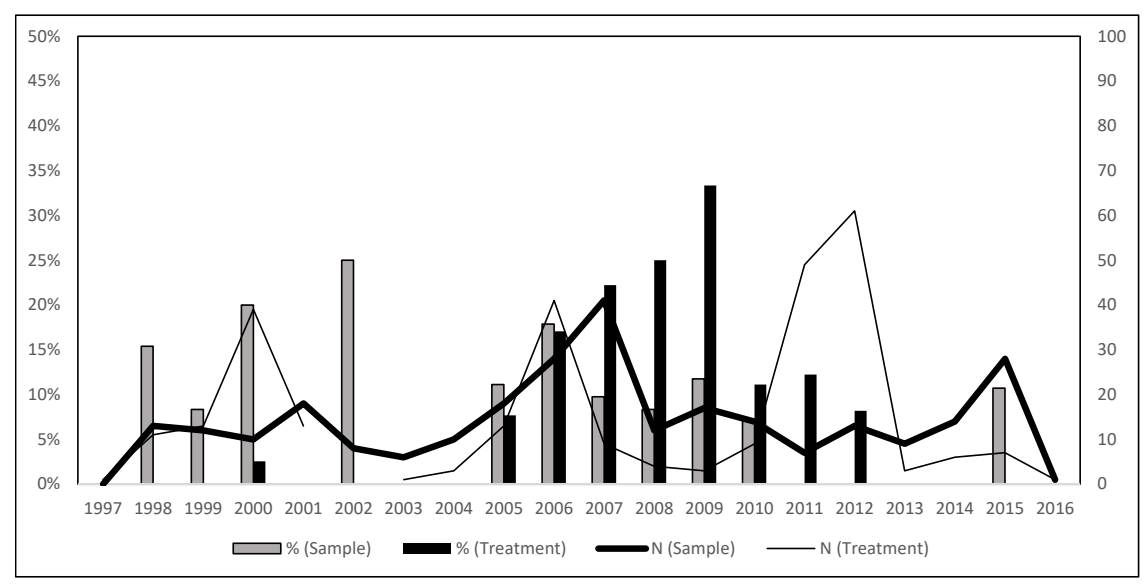

FIGURE 17. Percentage and frequency of references to "rebellious Armenians" in news media over time.

Media's striving for procedural fairness is commonly reflected in a tendency to cite players from opposing sides and a reliance on actors in positions of high authority in reporting about conflicts. Our data show that journalists apply both these strategies when reporting debates about the Armenian genocide. While media strongly support genocide claims, articles also present arguments used by those who challenge acknowledgment and criminalization of denial. They reference political motives of actors $(20.2 \%)$ and concerns about free speech issues (22.2\%), the latter especially in the context of criminalization debates, concerns about Turkey's position in international relations (49.2\%), and the health of French-Turkish relations (39.2\%). Some articles speak to Armenian militancy $(8.8 \%)$, potentially weakening the legitimacy of Armenian claims, and many argue that both sides of the divide present at least some legitimate arguments (49\%).

Our analysis also confirms media reliance on holders of high political office from both sides of the divide. The most frequently mentioned actor in the sample of articles, in fact, is the Turkish president (previously prime minister) Recep Tayyip Erdoğan (12.4\%); two other leading Turkish politicians are also cited relatively frequently (Ahmet Davutoğlu and Abdullah Gül, each just above 4\%). On the French side, presidents dominate, all of them proponents of acknowledgment of the Armenian genocide and criminalization of its denial. They include Nicolas Sarkozy (8.6\%), Jacques Chirac (5.1\%), and François Hollande (5.1\%). Other individual actors are cited far less frequently.

Arguments intended to weaken the legitimacy of the Armenian side emerge primarily in the context of political conflicts over acknowledgment and denial, as shown in Figure 17. We see that the percentage of references that highlight the militancy of Armenian insurgency is higher during periods of political or legal disputes (bars, left $y$-axis). The same applies to the frequency of those references (curve, right $y$-axis). The figure shows further that this effect is primarily due to 
reports about political or legal disputes (dark bar graph and line) compared to articles on the genocide as such (gray bar graph and dotted line).

Other rules of the journalistic game reflect the nature of the medium itself. Because of time and space constraints, journalistic reports about mass violence often simplify, focusing on the most dramatic (and quantifiable) events and portraying conflicting parties in overly streamlined ways. Previous studies have found-in reporting on African conflicts-that opposing parties are frequently presented as primordial ethnic or racial groups (e.g., Allen and Seaton 1999; Crilly 2010; McNulty 1999; Thompson 2007). Might this pattern apply to journalistic depictions of Turks and Armenians as well?

Our analysis reveals remarkable patterns. Consider specific forms of victimization. Most articles (45.7\%) explicitly speak to killings and many (16.2\%) to displacements. Journalists only rarely mention rapes (1.1\%), kidnappings $(1.2 \%)$, the appropriation of Armenian property (1.2\%), lack of food and water (4.1\%), or disease $(1.8 \%)$. The rarity of reporting of other forms of victimization starkly contrasts with most historical studies, which engage with the entire range of victimization to which the Ottoman Armenians were exposed. Space constraints are one likely contributor to such omissions.

In line with previous research on other violent conflicts, journalistic references to differentiations within each of the conflicting groups during the unfolding of the genocide are rare. Yet some journalists report dissent within contemporary Turkish society. A March 17, 2015, article in Le Monde ("Editorial” section, p. 15), by staff writer Marie Jégo, addresses Turkish civil society as a motor toward reconciliation with Armenia, listing the many "brave" Turkish intellectuals who engage in difficult "memory work." Furthermore, on April 25, 2007, Sophie Shihab published an article in Le Monde ("International" section, p. 4) about Kurds in the southwest of Turkey who commemorate the genocide and accept (co-)responsibility. Such depictions of conflicting parties within Turkey seek to open up avenues for understanding and reconciliation. In doing so, they simultaneously encourage future acknowledgment of the genocide.

One important constraint on media is the markets in which they operate. Survival depends on sales and ratings. Sales and ratings, in turn, depend on consumers' level of interest and the degree to which reports make sense to them. Especially in the commercialized segments of the media field, journalists thus seek to stir excitement and to dramatize representations. South African dramaturgist Jane Taylor put it well when she wrote about opportunities for dramatization in the realm of grave human rights violations, specifically regarding the role of perpetrators (quoted in Payne 2008:16): "What makes the stories of perpetrators so compelling is, in part, that they are agents: they act upon others. All of the psychological structures of desire, power, greed, fear, identification are invoked in these accounts. Milton's classic dilemma in Paradise Lost was that Satan became the hero of the narrative, because of the inherent interest in his character." 
Unsurprisingly, journalists tend to play to preconceptions among consumers of news. In an era of human rights hegemony, we expect them to write about the genocide against the Armenians within the human rights frame; to interpret the violence as criminal, in line with the Genocide Convention; to identify perpetrators; and to link this genocide to others about which the public has reached a broad consensus. In our sample, the relative majority of articles (29.5\%) indeed interpreted the aggression against the Armenians as a form of criminal violence and those who executed it as violent criminals. This percentage is especially important, given that half of all articles that do not deal with the violence per se, but rather with disputes over acknowledgment or denial, do not frame the acts of aggression themselves. To support the crime frame, many articles address the mens rea, the violators' mental state, as a necessary ingredient of crime, especially the crime of genocide. In fact, 25.8 percent of articles explicitly confirm intent. Within those, journalists most often identify the (Ottoman) state $(46.4 \%)$ and the Young Turks (5.3\%) as perpetrators. An article by Le Monde correspondent Jerôme Gautheret of April 23, 2015, provides an excellent example, elaborately reconstructing events and statements by the successors of the Young Turk government. Gautheret here quotes a December 13, 1918, pronouncement from the Turkish Ministry of the Interior: "During the war, our leaders applied ... the law of deportations in a way that exceeds the infamy of the most bloodthirsty bandits. They decided to exterminate the Armenians, and exterminate them they did. The decision was made by the Central Committee of the CUP [Committee of Union and Progress] and was implemented by the government" (Le Monde, April 23, 2015, supplement, p. 5; translated).

Referencing other, generally recognized, mass atrocities is another means of attributing meaning to a debated event. This includes analogical bridging-the referencing of past atrocities that have taken cultural shape to shed light on new or debated episodes of violence. In our sample of articles about the Armenian genocide, a quarter $(25.8 \%)$ indeed refer to other mass atrocities as points of comparison. Of these, about two-thirds ( $16.7 \%$ of total) cite the Shoah. To be sure, at times journalists reference the Holocaust to draw a distinction with the Armenian genocide, most commonly in reports about the criminalization debate. Yet, because most readers of journalistic reporting understand the Holocaust as the ultimate evil of the twentieth century and because the genocide convention grew out of this dark chapter of human history, frequent bridging indicates that the media seek to appeal to the known in order to dramatize the Armenian genocide.

Media reports resort to analogical bridging especially in the context of disputes over denialism, which supports my central argument about the counterproductive effects of denial in an age of a human rights hegemony. A 2011 article in Le Monde, for example, reports on a state visit by President Sarkozy to Armenia. The article quotes the president, who was "profoundly moved" by the genocide memorial. It "evoked memories of Yad Vashem-in Israel-and of the genocide museum of Kigali-in Rwanda." Sarkozy continued that Armenia is "in 
the heart of all French people [because] from the tragedy of the genocide was born our alliance" (Le Monde, October 2011, "Europe" section, p. 4; translated).

In sum, news media, when reporting on the Armenian genocide and struggles over its recognition, reinforce a human rights hegemony. It is true that they strive for balance in their reports, quoting prominent representatives from both sides of the divide. Yet they nonetheless tend to frame the violence as an instance of crimes committed in violation of human rights principles. They point to specific perpetrators and their exterminationist intent. At times, they even use, or report, analogical bridging to the Shoah, thereby comparing the Armenian genocide to that which the public perceives as the ultimate evil in modern history.

\section{Documentary Films, Acknowledgment of Genocide, and Effects of Denialism}

Documentary films reinforce the dominant message in U.S. and French news media. An analysis of ten films reveals factual and interpretive denial by Turkish authorities and suggests that filmmaking became one strategy to challenge denialist claims.

Consider the film Aghet-Ein Völkermord (Aghet-a genocide), produced in 2010 by ARD, Germany's public media giant. This documentary offers a chronological depiction of the Armenian genocide, supported by archival sources from multiple countries. Footage of Turkish denialism leads into a chronological reconstruction of events before, during, and after the genocide. The film intersperses actors reading excerpts from archival reports, as though they are the author relaying the information, with narration expanding on the reports, accompanied by footage of the atrocities. Focusing on conditions leading to the genocide, its execution, and responsible actors, the film seeks to prove that the Young Turksunder the leadership of Talaat Pasha, Enver Pasha, and Jamal Pasha-carried out a planned, systematic annihilation of the Armenian people. Deportations and death marches are thoroughly covered.

This and other films dramatize their depiction of the Armenian genocide by building analogical bridges to the Shoah. Aghet reports, for example, how "in 1934 the body of Talaat Pasha was sent by the Nazis with a pompous state ceremony from Berlin to Turkey" (1:18:50). It establishes a further link by quoting the infamous words attributed to Hitler, "Who still talks today about the annihilation of the Armenians?" (1:19:12). Footage from Nazi Germany explicitly draws parallels to the Armenian genocide (1:18-1:20). The message is further underlined when the film quotes Raphael Lemkin's conclusion that the Young Turks' actions "seemed . . . like a blueprint for the Hitlerian Holocaust and further genocide" (1:20:29) or words by Patrick Devedjian, a French minister and close advisor to President Sarkozy, who challenged Turkish denial with these words: "It is as if the Nazi government members were generally honored in today's Germany" (1:22:26).

We find similar themes and links to the Shoah in other films. Destination Nowhere: The Witness (2003) tells the story of Armin Wegner, a German medic 
during World War I who took many of the iconic photographs of the genocide. Inspired by his traumatic observations on the way to the Syrian Desert, Wegner later raised his voice against Hitler's rise to power. This film thus adds at least an indirect historical link between the Armenian genocide and the Holocaust. My Son Shall Be Armenian, a 2004 documentary, follows six people traveling through Armenia to gather stories and connect to their Armenian heritage. Directed by Hagop Goudsouzian, the film frames the violence as genocide. A quotation from a New York Times article about "Another Armenian Holocaust" (20:23) is followed by video footage from the Syrian Desert (21:04) and photographs of deportation routes to Deir ez-Zor (21:10). Screamers, a 2006 film about an Armenian American metal band with a mission to inform its listeners about genocide, focuses on the Armenian genocide but presents footage from the Holocaust, Rwanda, Yugoslavia (Srebrenica/Sarajevo), and Darfur as well. It also mentions Pol Pot's Cambodia and Stalin's Russia, at times building direct links to the Armenian genocide. Finally, Secret Histories: The Hidden Holocaust builds analogical bridging into its title and follows up with explicit references. The narrator reports, over imagery of caves, "Into these caves were tipped literally thousands of women and children," calling them a "Subterranean Auschwitz" (25:45). The film refers to a "Scene of the century's first Holocaust" (29:27) and concludes that Turkish denial is "in some ways identical" to denial by Neo-Nazis when they say that the "Nazi Holocaust against Jews never happened." Other documentaries, such as Voices from the Lake (2003), graphically depict the mass violence and use a genocide frame, but without bridging it to the Shoah.

In short, documentary films seem to parallel curricular guidelines, memorials, official recognitions, and a majority of media reports. Filmmakers suggest that denial motivated their drive to acknowledge. Most seek to shed light on the Armenian genocide by building analogical bridges to the Holocaust.

\section{CONCLUSIONS}

Case studies from the political and legal fields in France and the United Statesbegun in chapters 7 and 8 , respectively, and continued here-demonstrate the power of human rights hegemony. Power struggles at the level of concrete decision making may yield partial victories to denialist actors. Yet those turn out to be Pyrrhic victories under conditions of human rights hegemony. Just as hegemony prevents grave problems from becoming issues in public consciousness and in politics, so it precludes the denial of problems that are broadly recognized. State actors and NGOs are driving forces in securing human rights hegemony and acknowledgment of mass atrocity. Journalists and documentary filmmakers strengthen their case. In the context of human rights hegemony, efforts at denial yield counterproductive consequences, reinforcing the understanding of the mass violence against the Armenians of the Ottoman Empire as a case of genocide. 